\title{
NEW GENERA AND SPECIES OF TYRINI FROM AUSTRALIA (COLEOPTERA: PSELAPHIDAE)*
}

\author{
By Donald S. Chandler \\ Department of Entomology \\ University of New Hampshire \\ Durham, NH 03824
}

While preparing a paper on the pselaphid genera of Australia, three groups of the Tyrini, subtribe Tyrina, were discovered which could not be placed within the current generic concepts of the Australian fauna. One of these groups appears to be congeneric with Tyrogetus Broun from New Zealand, while the other two represent undescribed genera. With the recognition of these taxa, the major generic components of the Tyrini appear to be described for Australia.

All measurements are in millimeters. Slides of cleared and disarticulated specimens were used to determine the patterns of foveation of the genera. Holotypes are placed in the Australian National Insect Collection, Canberra, or in the National Museum of Victoria, Abbotsford.

\section{Tyrogetus Broun}

Tyrogetus Broun is represented by two species from New Zealand, optandus Broun (figured by Jeannel 1962:448) and palpalis Broun. Three undescribed species from Tasmania are very close to these New Zealand species based on the suite of characters used to differentiate genera in the Tyrini. The two New Zealand species are easily separated by tergite I being five times the length of II, while the length of tergite $I$ in the three Tasmanian species is about twice the length of II. The maxillary palpi of one Tasmanian species (occidentalis n. sp.) is relatively robust, while the palpi of the New Zealand species are more elongate and narrow, and the palpi of the two other Tasmanian species are the longest and narrowest. The relative lengths of the tergites and form of the maxillary palpi are

*Scientific Contribution Number 1461 from the New Hampshire Agricultural Experiment Station.

Manuscript received by the editor January 5, 1987. 
often used in conjunction with other characters to discriminate genera in the Tyrini. However, all other features used to separate tyrine genera are uniform in these species, and, coupled with the identical suite of foveae and quite similar general appearance, it is readily apparent that these five species form a monophyletic group. At this time I prefer to take a conservative course and place the undescribed Tasmanian species in Tyrogetus without division into subgenera or genera, at least until the New Zealand fauna is better known.

Tyrogetus Broun is characterized by: Body smooth, legs rugosely pebbled; head nude with vertexal foveae placed laterally above eyes, nude antero-median fovea at base of antennal tubercle, antennae with apical three flagellomeres forming club, segments II-IV of maxillary palpi elongate and basally pedunculate, 1 gular fovea; pronotum lacking antebasal foveae or sulcus, prosternal foveae present; elytra with two basal foveae; lateral mesosternal foveae broadly meeting internally, with small anterior fork, shallow median mesosternal fovea, lateral mesocoxal foveae placed posterior to mesocoxae, with median metasternal fovea; metasternum short, longitudinally tumid between meso- and metacoxae, metacoxae abruptly strongly protruding at junction with trochanters; abdomen with tergite I two to five times length of II, II-IV subequal, III shorter than IV, I with three basolateral foveae, anterolateral foveae small, II-IV with two baso-lateral foveae separated or partially fused, V with single baso-lateral fovea; sternites II-III deeply incised laterally at base (only visible on cleared specimens), incision joining globular invagination medially, IV-VI lacking basolateral foveae.

\section{Key to Tasmanian TyRogetus}

1. Fourth segment of maxillary palpi no more that three times as long as wide, basal third abruptly narrowed (Fig. 1); eyes with about 15 facets .................... occidentalis $n$. sp. Fourth segment of maxillary palpi five times or more as long as wide, gradually narrowed (Fig. 5); eyes with 10 or fewer facets ..................................

2. Length 1.5-1.8; males with paired teeth at apex of fifth tergite (Fig. 7); southwestern Tasmania ........... howardi $\mathrm{n}$. sp. Length 1.3; male lacking teeth at apex of fifth tergite; northeastern Tasmania .....................minimus $n$. sp. 


\section{Tyrogetus occidentalis $\mathrm{n}$. $\mathrm{sp}$.}

(Figs. 1-4)

Length 1.68-1.77. Body with moderately dense appressed setae; maxillary palpi with last segment angulate and directed laterally in apical two-thirds, abruptly swollen at point of angulation; eyes with about 15 facets; elytra with discal stria extending past middle; tergite I twice length of II, II as long as IV, III three-fourths length of II, V with narrowly truncate apex, apex slightly indented; protrochanters with stout swollen ventral knob, profemora with flattened carina on inner margin from near base to middle, protibia with small spur at apex.

Males with sternites II-IV flattened medially, V with shallow longitudinal groove.

Females with sternites II-V medially convex.

Measurements of holotype: Maxillary palpi with fourth segment 0.06 wide, 0.16 long; tergite I 0.33 long, II 0.17 long, III 0.13 long, IV 0.18 long, V 0.07 long; carina on profemora 0.17 long.

Specimens examined, 6: Holotype male, Tasmania, Mt. Field National Park, near SE end Lake Fenton, 1000 m, I-30/II-5-1980, A. Newton \& M. Thayer, Nothofagus gunnii-Richea spp.-Arthrotaxis spp.-Phyllocladus asplen. forest (ANIC). Paratypes: 1 male, Hartz Mountains National Park, Hartz Road, 740 m, II-8/ 10-1980, Eucalyptus-Nothofagus, A. Newton \& M. Thayer, berlese forest leaf \& $\log$ litter (DSC); 1 male, Willie's Saddle, $9 \mathrm{~km}$ W Geeveston, 370 m, II-8/10-1980, A. Newton \& M. Thayer, Eucalyptus forest, berlese forest leaf $\&$ log litter (AFN); 1 female, Great Lakes, C. Oke (MVMA); 1 male, 1 female, no locality, C. Oke collection (MVMA). Found in the southwestern half of Tasmania.

Discussion: This species is quite similar in general appearance to palpalis Broun. In occidentalis tergite I is shorter, flagellomere VII is wider than VI and forms the base of the antennal club, and the last segment of the maxillary palpi is expanded in the apical twothirds. Palpalis has tergite I longer, flagellomere VII is barely wider than VI so the antennal club appears almost two-segmented, and the last segment of the maxillary palpi is expanded in the apical half.

Etymology: The name is derived from the distribution in the western portion of Tasmania. 

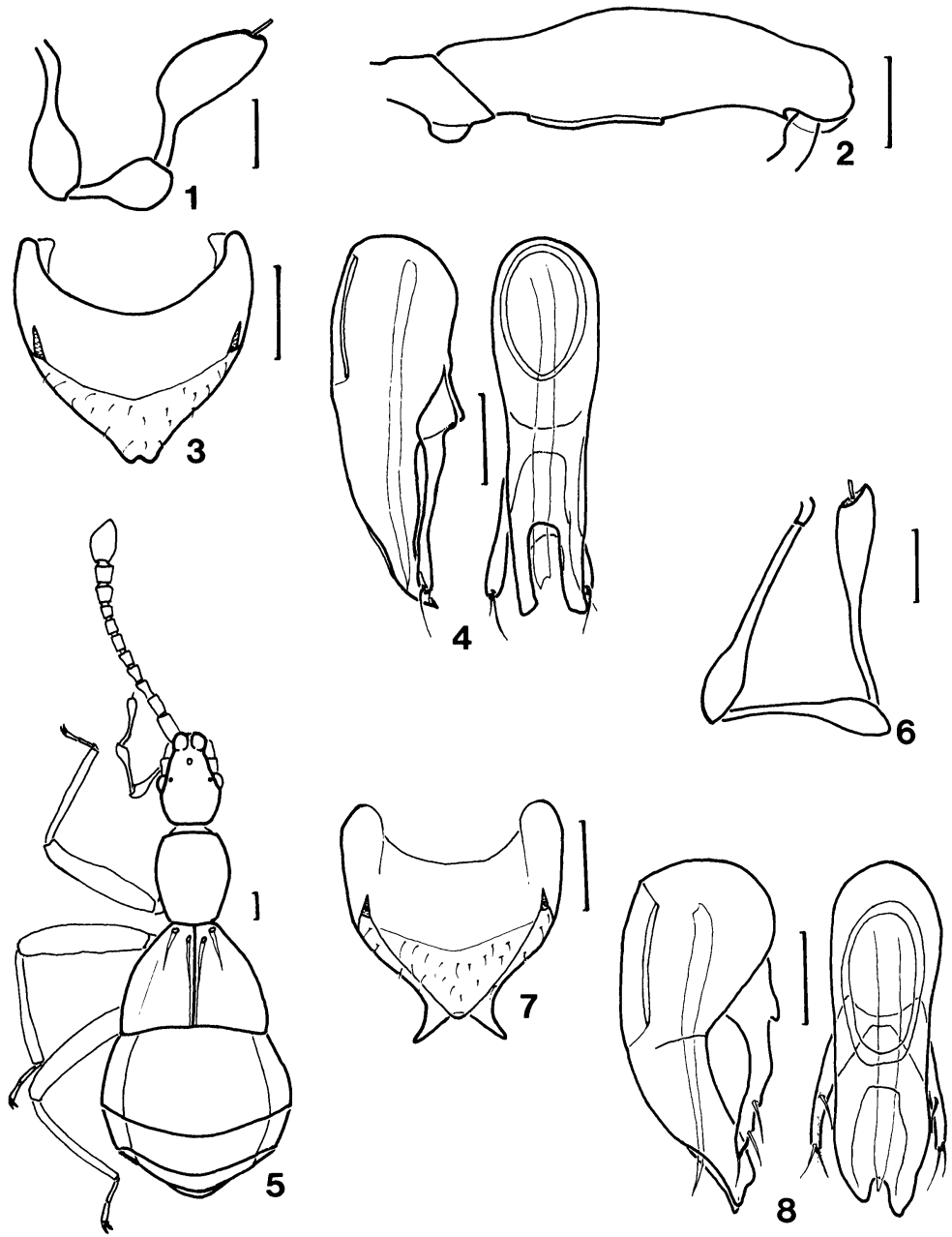

Line to right of figures is equal to $0.1 \mathrm{~mm}$.

Figs. 1-4. Tyrogetus occidentalis $\mathrm{n} . \mathrm{sp}$. 1. Dorsal view right maxillary palpus; 2. posterior view right profemur; 3 . dorsal view tergite $V ; 4$. right lateral and dorsal view male genitalia.

Figs. 5-8. Tyrogetus howardi $\mathrm{n}$. sp. 5. Dorsal habitus; 6. dorsal view right maxillary palpus; 7 . dorsal view tergite $\mathrm{V}$; 8 . right lateral and dorsal view male genitalia. 
Tyrogetus howardi $\mathrm{n}$. sp.

(Figs. 5-8)

Length 1.50-1.74. Body with sparse short appressed setae; eyes small, with 8-10 facets, maxillary palpi elongate-pedunculate, with stems longer than swollen areas, last segment narrowly swollen beyond midpoint; elytra with discal stria indistinct past middle; tergite I twice as long as II, II and IV subequal, III over half as long as II, V longitudinally carinate with two lateral teeth at apex; metasternum strongly tumid and carinate between meso- and metacoxae; profemora with narrow elongate oval smooth area on antero-mesal margin delimited by fine carina.

Males with sternites III-V barely flattened medially, VI with faint circular impression through entire length.

Females with sternites III-V convex medially.

Measurements of holotype: Maxillary palpi with fourth segment 0.03 wide, 0.24 long; tergite I 0.36 long, II 0.16 long, III 0.09 long, IV 0.15 long, V 0.07 long; smooth area on profemur 0.24 long.

Specimens examined, 9: HolOTYPE male, Tasmania, Lower Gordon River, 42.43S 145.45E, 42.43S 145.50E, II-3-1977, Howard \& Hill, HEC Survey, litter (ANIC). PARATYPES: 1 female, same data as holotype (ANIC); 1 female, same data except II-8-1977 (ANIC); 1 male, Lower Gordon River, 42.42S 145.53E, 42.41.5S 145.53E, II-31977, Howard \& Hill, HEC Survey, litter (DSC); 1 female, Lower Gordon River, 42.42S 145.48E, 42.41S 145.49E, II-13-1976, Howard \& HIll, HEC Survey, moss (DSC); 1 male, Lower Gordon River, 42.48.5S 145.51E, 42.48S 145.54E, III-1-1977, Howard \& Hill, HEC Survey, moss (DSC); 1 female, same data except III-41977, litter (ANIC); 1 male, Willie's Saddle, 9 km W Geeveston, 310 m, II-8/10-1980, A. Newton \& M. Thayer, Eucalyptus forest, berlese forest leaf \& $\log$ litter (AFN); 1 male, Mt. Field National Park, Lake Dobson Road, 710 m, I-30/II-5-1980, A. Newton \& M. Thayer, Nothofagus-Eucalyptus forest, berlese forest leaf \& log litter (AFN). Found in the southwestern half of Tasmania.

Discussion: Howardi n. sp. shares with minimus n. sp. the reduced eyes and elongate palpi which are only narrowly enlarged apically. Howardi is larger than minimus, the last tergite of the male is produced into two teeth at the apex, and the aedeagus is deeply emarginate at the apex. 
Etymology: Named for C. Howard, who collected many pselaphids during the H. E. C. Survey of the Lower Gordon River.

\section{Tyrogetus minimus n. sp.}

(Fig. 9)

Length 1.29. Body with sparse short appressed setae; maxillary palpi elongate-pedunculate, last segment with apical half narrowly enlarged, eyes with 6-7 facets; elytra with discal stria not reaching to middle; tergite I twice as long as II, II almost twice as long as III, II and IV subequal, $\mathrm{V}$ with strong median carina through apical half of length; metasternum short, strongly tumid between meso- and metacoxae.

Males with transverse impression through length of sternite V.

Females unknown.

Measurements of holotype: Maxillary palpi with fourth segment 0.04 wide, 0.24 long; tergite I 0.28 long, II 0.13 long, III 0.07 long, IV 0.11 long, V 0.06 long.

Specimen examined: HolotyPe male, Tasmania, $4.4 \mathrm{~km}$ SE Weldborough, $460 \mathrm{~m}$, II-12/14-1980, A. Newton \& M. Thayer, Nothofagus, etc. forest, berlese forest leaf \& log litter (ANIC). Found in northeastern Tasmania.

Discussion: Quite similar in general appearance to howardi n. sp. by the reduced eyes and narrowly swollen maxillary palpi. Separated by the smaller size, simple apex of the last male tergite, and the broadly protruding apex of the aedeagus.

Etymology: The name was suggested by the small size of this species.

Tasmanityrus n. gen.

Tyromorphus auricomus Lea is an anomaly in Tyromorphus Raffray (17 species, Australia and Tasmania). It is somewhat similar in general appearance to the members of Tyromorphus, but differs conspicuously in the form of the maxillary palpi, which are elongate and pedunculate in auricomus (Fig. 10) and are radically different from the short, stout apical segments in Tyromorphus (Fig. 11). It is surprising that Lea placed auricomus in this genus, since the palpal form actually approaches that of Gerallus Sharp (8 species, Australia and Tasmania), with the fourth palpal segment of Gerallus being more fusiform and only narrowly pedunculate at the base (Fig. 12). 

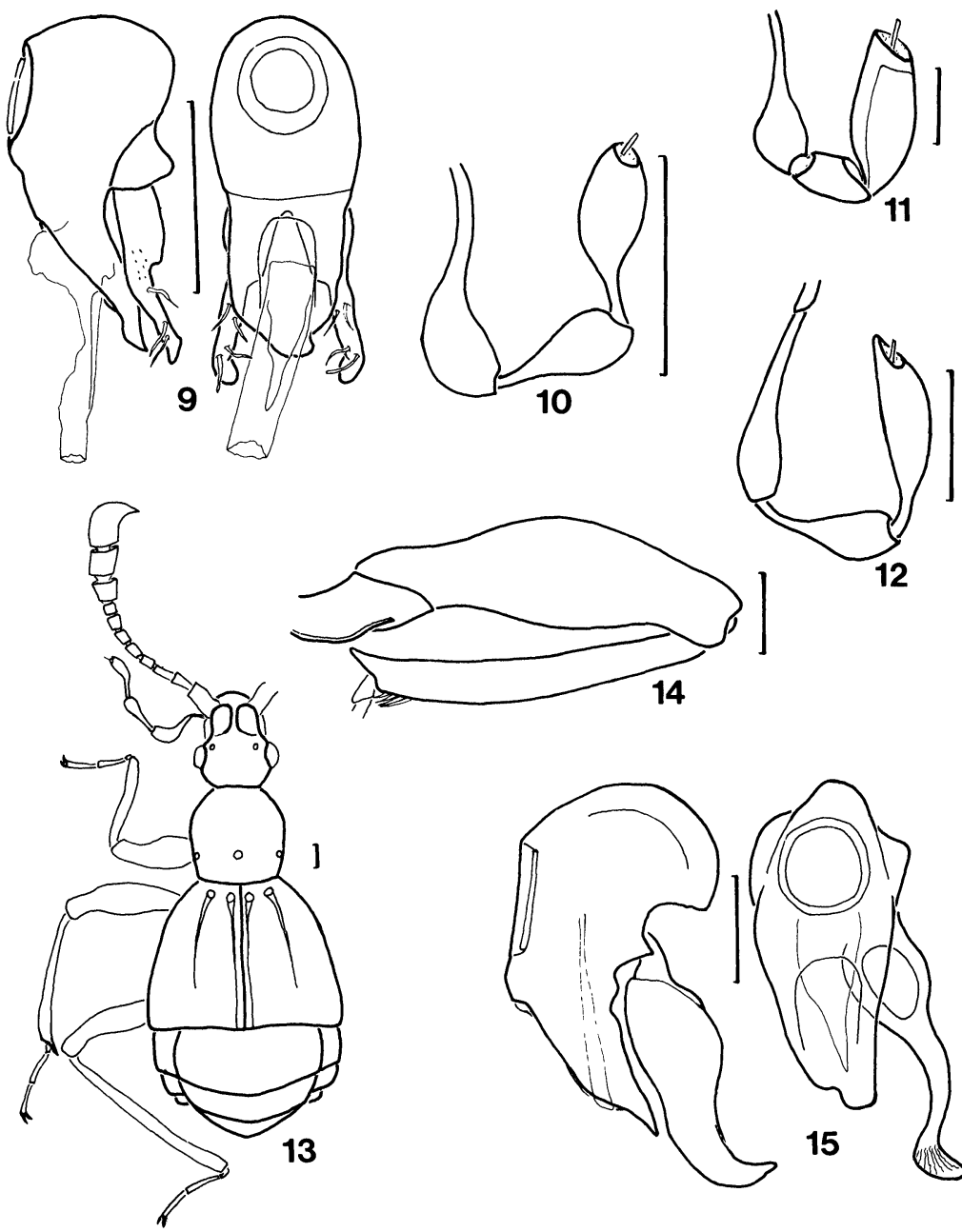

Fig. 9. Tyrogetus minimus n. sp., right lateral and dorsal view male genitalia.

Fig. 10. Tasmanityrus auricomus (Lea), dorsal view right maxillary palpus.

Fig. 11. Tyromorphus comes (Schaufuss), dorsal view right maxillary palpus.

Fig. 12. Gerallus palpalis (King), dorsal view right maxillary palpus.

Fig. 13-15. Tasmanityrus hilli $\mathrm{n}$. sp. 13. Dorsal habitus; 14. posterior view right middle leg; 15. right lateral and dorsal view male genitalia. 
The suite of male characters used in discrimination of species of Gerallus and Tyromorphus occur in different areas of the body for each genus. Tasmanityrus possesses only a few simple male characters on the mesotrochanters and mesotibiae, which occur in many other genera, but with the unique feature of having lost either the right or left paramere. The remaining paramere is more developed than in groups with two parameres, and projects to either side. In Gerallus the parameres are free and elongate, while in Tyromorphus they are reduced and symmetrical. Based on the aedeagal characters, the male cuticular modifications, and the palpal form, it is clear that this is a monophyletic group of seven very similar species which is perhaps closest to, but distinct from, Gerallus.

Type species, Tyromorphus auricomus Lea. Gender of genus, masculine.

Tasmanityrus n. gen. is characterized by: head with nude vertexal foveae, paired gular foveae, segments II-IV of maxillary palpi clearly pedunculate at base, antennal club of last three flagellomeres; prothorax with small median and lateral antebasal foveae, lacking transverse antebasal sulcus, procoxal foveae present; elytra with two large basal pubescent foveae, discal stria distinct past middle of elytra; tergite I with three basolateral foveae, anterior foveae small, II-V with single basolateral fovea; sternites II-III and V with deep sulci at basolateral margins extending medially and then abruptly curving anteriorly, II with large baso-lateral foveae medial to sulcal incision, with deep transverse sulcus between medial foveae, two teeth projecting anteriorly from posterior margin of sulcus at inner margin of metacoxae; mesosternum with large lateral mesosternal foveae meeting medially, with small anterior branches, median mesosternal fovea present, lateral mesocoxal foveae present, median metasternal fovea present.

Females are very similar and are associated with males solely on the basis of identical collection data. The genitalia of all males, except for those of hilli $\mathrm{n}$. sp. which have differently modified male mesotrochanters, were extracted to check identification. Two species were collected at several sites, but the data associated with the specimens collected by John Kethley indicate that these species were found in different leaf litters. The following key is based only on male features. Males may be recognized by the modified mesotrochanters, the large apical mesotibial spur, and sternites medially flattened to concave. Also, males tend to have the outer face of the mandibles bearing a more conspicuous medial tooth. 


\section{Key to Species of TASManityrus (MALeS)}

1. Mesotrochanters carinate ventrally (Fig. 14), mesotibial spurs small, barely longer than first mesotarsomeres ...... hilli $\mathrm{n}$. sp. Mesotrochangers with ventral tooth (Fig. 16), mesotibial spurs $1.4 \times$ or more as long as first mesotarsomeres ............

2. (1) Apical flagellomeres at most barely curved ventrally in apical half, ventral margin nearly straight; northeastern Tasmania .... ................................ simplicis $\mathrm{n}$. sp. Apical flagellomeres strongly curved ventrally toward apex, outline strongly concave in lateral view (Fig. 13) ............

3. (2) Right paramere developed, longer than penis (Fig. 17); southwestern Tasmania.................. newtoni $\mathrm{n} . \mathrm{sp}$. Left paramere developed .......................4

4. (3) Penis apex acute, paramere abruptly curved laterally at apex (Fig. 19); southwestern Tasmania ......... auricomus (Lea) Penis apex broadly truncate or broadly asymmetrical, paramere differently formed (Figs. $20-22$ ) . . . . . . . . . . . . . .

5. (4) Mesotrochanteral spurs and apical spur of mesotibiae same length; northeastern Tasmania........... orientalis $\mathrm{n} . \mathrm{sp}$. Mesotrochanteral spurs at most two-thirds length of apical spur of mesotibiae ............................ 6

6. (5) Penis apex symmetrical, paramere broadly rounded to medial point; southwestern Tasmania ............. thayeri $\mathrm{n} . \mathrm{sp}$. Penis apex asymmetrical with left margin protruding, paramere apex truncate and acutely angled laterally; northwestern Tasmania ........................ septentrionalis $\mathrm{n} . \mathrm{sp}$.

\section{Tasmanityrus hilli $\mathrm{n}$. sp.}

(Figs. 13-15)

Length 1.83-2.01. Male with deep oblique ventral impression on last flagellomere, penultimate flagellomere asymmetrical, obtusely produced on ventral margin; mesotrochanters carinate ventrally, mesotibiae with apical spur as long as first tarsomere, spur acutely pointed at apex; aedeagus with asymmetrical apex, right paramere strongly developed, flattened and twisted ventrally, expanded at apex.

Measurements of holotype: Flagellomere VII 0.10 wide, 0.11 long; VIII 0.11 wide, 0.12 long; IX 0.12 wide, 0.24 long; mesotibial spur 0.05 long, first mesotarsomere 0.06 long. 
Specimens examined, 109: Holotype male, Tasmania, W side Lake St. Clair, c. 750 m, I-25/29-1980, Nothofagus, etc., berlese leaf \& $\log$ litter (ANIC). PARATYPES: 4 males, 7 females, eutopotypical (AFN, DSC); 1 male, 3 females, St. Clair National Park, nr. Echo Point, II-11-1977, J. Kethley, Nothofagus cunninghami litter with fungal mat. (golden) (FMNH); 1 male, 5 females, Zeehan-Renison Bell St. Res., Scenic Drive, $250 \mathrm{~m}$, II-18-1980, A. Newton \& M. Thayer, Nothofagus, etc. (AFN); 1 male, 3 females, 10 mi SE Smithton, Savage River, III-5-1977, J. Kethley, very dry Nothofagus cunninghami litter (FMNH); 1 male, $40 \mathrm{~km} \mathrm{SW}$ Smithton, III-4-1977, J. Kethley, Acacia melanoxylon litter (FMNH); 28 males, 54 females, Lower Gordon River, many different latitude and longitude records, II-11-1976, I-21/III-1-1977, I-1978, Howard \& Hill, HEC Survey, moss, litter (ANIC, DSC). This species consists of most of the type-series of T. auricomus (Lea) from Waratah (ANIC, SAMA). Found in the southwestern two-thirds of Tasmania.

Discussion: The males are easily separated from the other species by the carinate mesotrochanters. Most similar to newtoni $\mathrm{n}$. sp. by the form and development of the right paramere, and the oblique impression on the venter of the apical flagellomere.

Etymology: Named for L. Hill, who collected many pselaphids during the HEC Survey on the Lower Gordon River.

\section{Tasmanityrus newtoni $\mathrm{n}$. sp.}

(Figs. 16-17)

Length 1.74-1.95. Male with apex of last flagellomere curved ventrally, acute, venter impressed in apical half, penultimate flagellomere somewhat flattened dorso-ventrally but otherwise symmetrical; mesotrochanters with ventral spine near base, mesotibiae with apically spatulate to pedunculate spur, almost twice as long as first tarsomere; aedeagus with symmetrical apex, right paramere strongly developed, flattened and twisted ventrally to subacute apex.

Measurements of holotype: Flagellomere VII 0.11 wide, 0.11 long, VIII 0.13 wide, 0.11 long, IX 0.14 wide, 0.24 long; mesotrochanteral spur 0.04 long, mesotibial spur 0.08 long, first tarsomere 0.05 long.

Specimens examined, 115: Holotype male, Tasmania, Mt. Field National Park, Lake Dobson Road, 610 m, I-30/II-4-1980, A. Newton \& M. Thayer, Nothofagus-Eucalyptus forest, berlese leaf \& $\log$ 

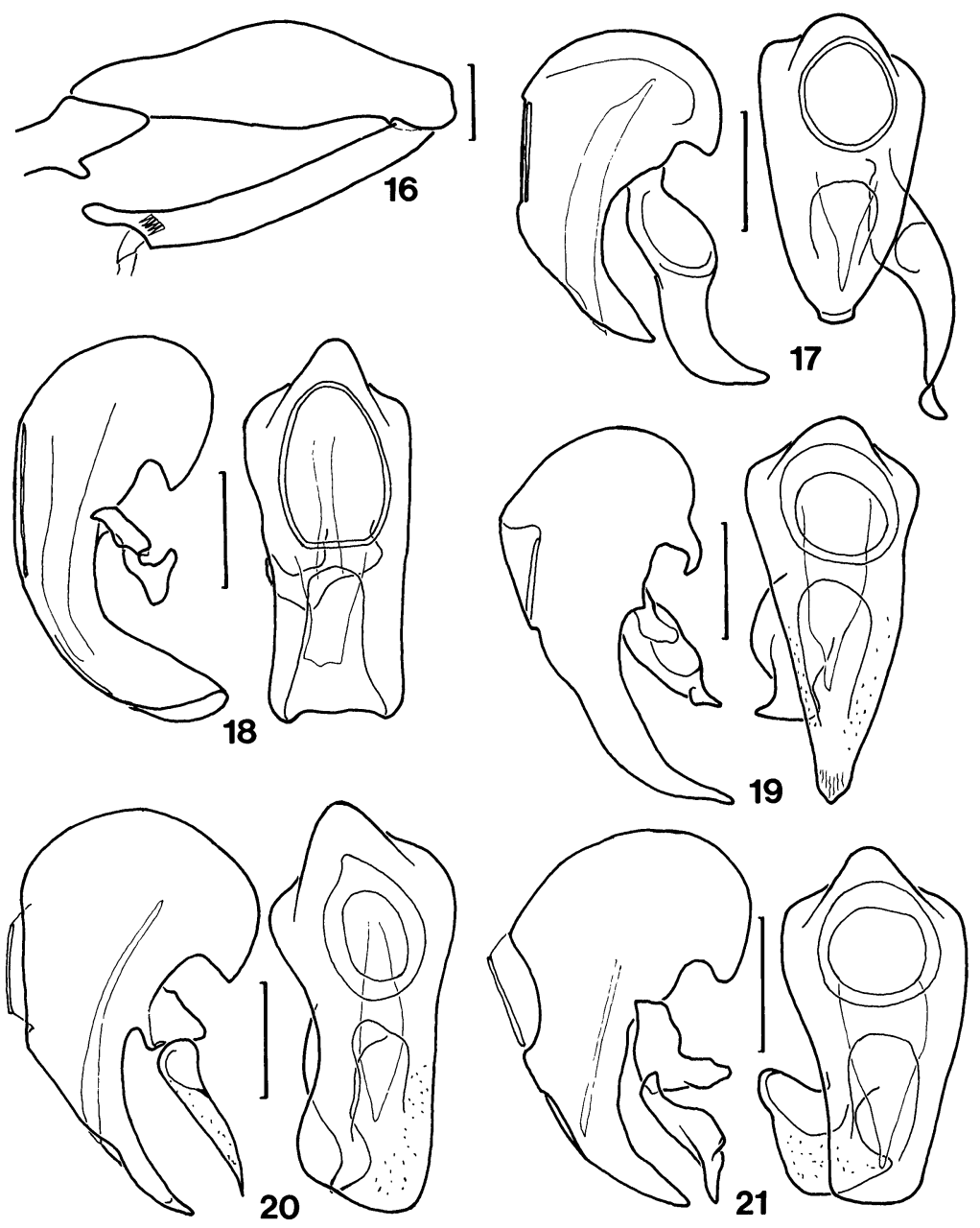

Fig. 16-17. Tasmanityrus newtoni $\mathrm{n}$. sp. 16. Posterior view right middle leg; 17. right lateral and dorsal view male genitalia.

Fig. 18. Tasmanityrus simplicis n. sp., right lateral and dorsal view male genitalia.

Fig. 19. Tasmanityrus auricomus (Lea), right lateral and dorsal view male genitalia.

Fig. 20. Tasmanityrus orientalis n. sp., right lateral and dorsal view male genitalia.

Fig. 21. Tasmanityrus thayeri $\mathrm{n}$. sp., right lateral and dorsal view male genitalia. 
litter (ANIC). PARATYPES: 1 male, 2 females, eutopotypical (DSC); 1 male, 3 females, same data except, 710 m, I-30/II-5-1980 (AFN); 3 males, 1 female, Willie's Saddle, $9 \mathrm{~km}$ W Geeveston, $310 \mathrm{~m}$, II-8/101980, A. Newton \& M. Thayer, Eucalyptus forest, berlese forest leaf \& $\log$ litter (AFN, ANIC); 1 male, The Gap, Florentine Road, 15 km WNW Maydena, 600 m, II-1-1980, A. Newton \& M. Thayer, Nothofagus, etc., berlese forest leaf \& $\log$ litter (AFN); 2 males, 2 females, Florentine Valley, $29.2 \mathrm{~km}$ WNW Maydena, on Eleven Road, 460 m, II-1/6-1980, A. Newton \& M. Thayer, Nothofagus, berlese forest leaf \& log litter (AFN, DSC); 11 males, 8 females, 22 km NW Maydena, Florentine Valley, 700', II-15-1977, J. Kethley, litter of Eucalyptus regnans \& Dicksonia antarctica in depression (DSC, FMNH); 1 male, 3 females, same data except, litter base of Eucalyptus (FMNH); 1 male, same data except, II-14-1977, Nothofagus cunninghami litter at base of log (FMNH); 3 males, $28 \mathrm{~km}$ NW Maydena, Derwent Valley, 800', II-16-1977, J. Kethley, mixed litter Nothofagus cunninghami \& Atherosperma moschatum (FMNH); 1 male, Hartz Mountains National Park, Hartz Road, $740 \mathrm{~m}$, II-8/10-1980, A. Newton \& M. Thayer, EucalyptusNothofagus forest, berlese forest leaf \& $\log$ litter (AFN); 1 male, 1 female, Hastings St. Res., near Newdegate Cave, 130 m, II-9-1980, A. Newton \& M. Thayer, trapped in floating debris, forest stream (AFN); 6 males, 16 females, Lower Gordon River, 42.56S 145.50E, 42.54S 145.54E, II-18-1977, Howard \& Hill, HEC Survey, litter (ANIC, DSC); 1 male, 3 females, same data except, 42.51.5S 145.48E, 42.40.5S 145.51.5E (ANIC); 5 males, 12 females, same data except, 42.48.5S 145.51E, 42.48.5S 145.54E, III-4-1977 (ANIC, DSC); 1 male, 3 females, Mt. Wellington, XII-24/26-1978, L. Hill (ANIC); 4 males, 6 females, $10 \mathrm{~km} \mathrm{NW} \mathrm{Hobart,} \mathrm{Mt.} \mathrm{Wellington,}$ I-27-1977, litter under Dicksonia antarctica (FMNH); 1 male, Mt. Wellington, Griffith (SAMA); 2 males, 6 females, Mt. Wedge, XII8-1982, S. Endrody-Younga, Nothofagus litter (TMSA); 1 male, 2 females, no locality (MVMA). Found in the southwestern half of Tasmania.

Discussion: The males are most similar to those of hilli by the form and development of the right paramere. Newtoni is easily separated from hilli by spurred mesotrochanters, long spatulate to pedunculate mesotibial spurs, and symmetrical penis apex.

Etymology: Named for A. F. Newton, Jr., who has collected many interesting Pselaphidae in Australia. 


\section{Tasmanityrus simplicis n. sp.}

(Fig. 18)

Length 1.95-2.16. Males with ventral margin of apical flagellomere straight or only slightly curved; mesotrochanters with ventral spine near base, mesotibiae with long curved spur narrowly rounded at apex, spur almost half again as long as first mesotarsomere; aedeagus with apex symmetrical, probable right paramere short, strongly recurved to left.

Measurements of holotype: Flagellomere VII 0.09 wide, 0.11 long, VIII 0.10 wide, 0.10 long, IX 0.12 wide, 0.24 long; mesotrochanteral spur 0.02 long, mesotibial spur 0.07 long, first mesotarsomere 0.05 long.

Specimens examined, 9: HolotyPE male, Tasmania, Mt. Barrow Road, 890 m, II-15/17-1980, A. Newton \& M. Thayer, Nothofagus, etc., berlese forest leaf and log litter (ANIC). Paratypes: 1 male, 3 females, eutopotypical (AFN, ANIC); 3 males, 1 female, track off Mt. Barrow Road, 780 m, II-15/17-1980, A. Newton \& M. Thayer, Nothofagus, etc., berlese forest leaf \& log litter (AFN, DSC). Found in the northeastern portion of Tasmania.

Discussion: Unique in the simple apical flagellomeres of the male, right paramere strongly recurved, and broad symmetrical apex of the aedeagus.

Etymology: The name is derived from the simple apical flagellomeres.

\section{Tasmanityrus auricomus (Lea), n. comb.}

(Figs. 10, 19)

Tyromorphus auricomus Lea 1911: 766, pl. 21, fig. 9. Holotype locality: Waratah, Tasmania. Holotype in South Australian Museum, Adelaide (SAMA).

Length 1.83-2.01. Males with last flagellomere curved ventrally to point at apex, with oblique ventral impression, impression and flattened adjacent portions of flagellomeres VII-VIII roughened, flagellomere VIII obtusely protruding on ventral margin; mesotrochanters toothed near base, mesotibiae with spatulate apical spur, spur half again as long as first mesotarsomere; aedeagus with symmetrical apex, left paramere developed, short and laterally curved abruptly to acute point at apex.

Measurements of specimen from Rufus Canal: Flagellomere VII 0.09 wide, 0.12 long, VIII 0.10 wide, 0.12 long, IX 0.12 wide, 0.26 
long; mesotrochanteral spur 0.04 long, mesotibial spur 0.08 long, first mesotarsomere 0.05 long.

Specimens examined, 33: Rufus Canal, $13.5 \mathrm{mi}$ WNW Derwent Bridge, $800 \mathrm{~m}, \mathrm{I}-26 / 28-1980$, A. Newton \& M. Thayer, Nothofagus rainforest, berlese forest leaf $\& \log$ litter; $28 \mathrm{~km} \mathrm{NW}$ Maydena, Derwent Valley, 800', II-16-1977, J. Kethley, mixed litter Nothofagus cunninghami \& Atherosperma moschatum on slope; Gordon River Road, 0.8 km W Florentine River, 550 m, II-3-1980, A. Newton \& M. Thayer, Nothofagus, etc., berlese forest leaf \& log litter; same data except, near Little Florentine River, $440 \mathrm{~m}$; The Gap, Florentine Road, $15 \mathrm{~km}$ WNW Maydena, $600 \mathrm{~m}$, II-1-1980, A. Newton \& M. Thayer, Nothofagus, etc., berlese forest leaf \& $\log$ litter; Florentine Valley, $22 \mathrm{~km} \mathrm{SW}$ Maydena, 700', II-15-1977, J. Kethley, ex: myrtle log and root mat; W side Lake St. Clair, c. 750 m, I-25/29-1980, A. Newton \& M. Thayer, Nothofagus, etc., wet leaves and floral debris, forest stream; Lake St. Clair National Park, S end Lake St. Clair, II-7-1977, J. Kethley, litter under Calystomen veridifloris; $40 \mathrm{~km}$ SW Smithton, III-4-1977, J. Kethley, Acacia melanoxylon litter; $64 \mathrm{~km} \mathrm{~S}$ Smithton; III-3-1977, J. Kethley, litter of Nothofagus cunninghami under ground fern, Blechnum sp. There is a specimen labeled as the holotype ("TY") by Lea on a card bearing four specimens (two males, two females) from Waratah, although this designation was not mentioned in the description. This specimen is accepted as the holotype. The male paratype on the card is a specimen of hilli $\mathrm{n}$. $\mathrm{sp}$, as are the paratypes from Waratah in the ANIC. The paratypes from the other type localities (Ulverstone, Mt. Wellington, Hobart) have not been seen. Specimens are present in the collections of: AFN, ANIC, DSC, FMNH, SAMA. Found in southwestern Tasmania.

Discussion: Closest to thayeri $\mathrm{n}$. sp. and orientalis $\mathrm{n}$. $\mathrm{sp}$. by the development of the left paramere. Separated by the spatulate mesotibial spur, protruding ventral apical margin of flagellomere VIII, and narrowed penis apex.

\section{Tasmanityrus orientalis $\mathrm{n} . \mathrm{sp}$.}

(Fig. 20)

Length 1.77-1.89. Males with oblique ventral impression on last flagellomere, sharply curved ventrally to point, flagellomere VIII only slightly protruding on ventral apical margin, nearly symmetri- 
cal; mesotrochanters with long spine near base, mesotibiae with long thick apical spur half again as long as first mesotarsomeres; aedeagus with broad asymmentrical apex, left paramere strongly developed, curved laterally and narrowing to point.

Measurements of holotype: Flagellomere VII 0.09 wide, 0.09 long, VIII 0.12 wide, 0.10 long, IX 0.13 wide, 0.26 long; mesotrochanteral spur 0.09 long, mesotibial spur 0.10 long, first mesotarsomere 0.05 long.

Specimens examined, 5: Holotype male, Tasmania, $4 \mathrm{~km} \mathrm{SE}$ Weldborough, $450 \mathrm{~m}$, II-12/14-1980, A. Newton \& M. Thayer, Nothofagus, etc., berlese forest leaf $\& \log$ litter (ANIC). PARATYPES: 1 female, eutopotypical (ANIC); 2 males, 1 female, same data except $4.4 \mathrm{~km}$ SE Weldborough, $460 \mathrm{~m}$ (AFN, DSC). Known from northeastern Tasmania.

Discussion: Closest to thayeri by the strong development of the left paramere, but easily distinguished by the asymmetrical penis apex and form of the paramere.

Etymology: The name is derived from its collection in northeastern Tasmania.

\section{Tasmanityrus thayeri $\mathrm{n} . \mathrm{sp}$.}

(Fig. 21)

Length 1.95-2.10. Male with apical flagellomere curved abruptly near apex to point, flagellomere VIII with ventral margin barely protruding at apex; mesotrochanters with ventral spine near base, mesotibiae with spatulate apical spur, spur half again as long as first tarsomere; aedeagus with broadly truncate apex, left paramere strongly developed, abruptly enlarged in apical half.

Measurements from holotype: Flagellomere VII 0.11 wide, 0.10 long, VIII 0.12 wide, 0.09 long, IX 0.13 wide, 0.22 long; mesotrochanteral spur 0.03 long, mesotibial spur 0.08 long, first mesotarsomere 0.05 long.

Specimens examined, 12: HolotyPe male, Tasmania, Mt. Field National Park, Lake Dobson Road, 240 m, I-30/II-5-1980, A. Newton \& M. Thayer, wet sclerophyll, berlese forest leaf \& log litter (ANIC). Paratypes: 3 males, 5 females, eutopotypical (AFN, ANIC, DSC); 1 male, Florentine Valley, $10 \mathrm{~km}$ NW Maydena, II-14-1977, J. Kethley, ex: Eucalyptus litter \& soil under log (FMNH); 1 male, Maydena, ANM Forest Station, 600', II-13- 
1977, J. Kethley, conc. pine litter (FMNH). One male specimen with weakly sclerotized genitalia is identified as this species but is not a designated paratype: E of Tooms Lake, IV-14-1977, L. Hill, litter ex: dry sclerophyll forest Eucalyptus obliqua (FMNH). Found in southern Tasmania.

Discussion: Close to septentrionalis and orientalis by the development of the left paramere and the broad penis apex. The broad symmetrical penis apex places thayeri closest to simplicis, but the form of the paramere and curved last flagellomeres easily separates these two species.

Etymology: Named for M. K. Thayer, who has collected many species of Pselaphidae in Australia.

\section{Tasmanityrus septentrionalis $\mathrm{n}$. $\mathrm{sp}$.}

(Fig. 22)

Length 1.86. Males with apex of last flagellomere curved ventrally, acute, venter impressed in apical half, penultimate flagellomere with antero-ventral angle at apex projecting; mesotrochanters with ventral spine near base, mesotibiae with long spatulate spur twice as long as first tarsomere; aedeagus with broad asymmetrical apex, left apical margin projecting, right paramere truncate at apex, acutely projecting laterally.

Measurements of holotype: Flagellomere VII 0.10 wide, 0.11 long, VIII 0.12 wide, 0.10 long, IX 0.13 wide, 0.23 long; mesotrochanteral spur 0.03 long, mesotibial spur 0.09 long, first mesotarsomere 0.04 long.

Specimen examined: HolotyPE male, Tasmania, $34 \mathrm{~km}$ W Smithton, Dismal Swamp, II-26-1977, J. Kethley, mixed Nothofagus cunninghami \& Acacia melanoxylon litter, base of Nothofagus cunninghami (ANIC). Found in northwestern Tasmania.

Discussion: The broad asymmetrical penis apex places this species closest to orientalis, with the apex being slightly produced on the left rather than right side. The form of the paramere easily separate the two species, with the paramere of septentrionalis being stouter and much more abruptly angulate at the apex.

Etymology: Named for its collection in extreme northwestern Tasmania. 

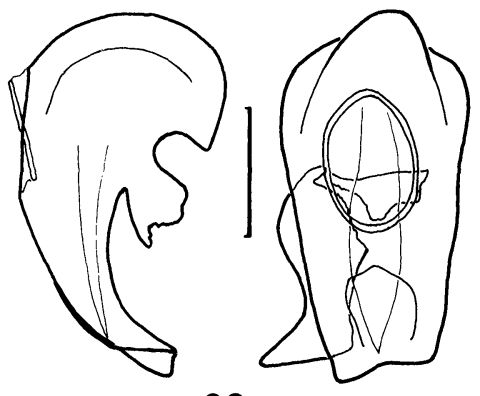

22
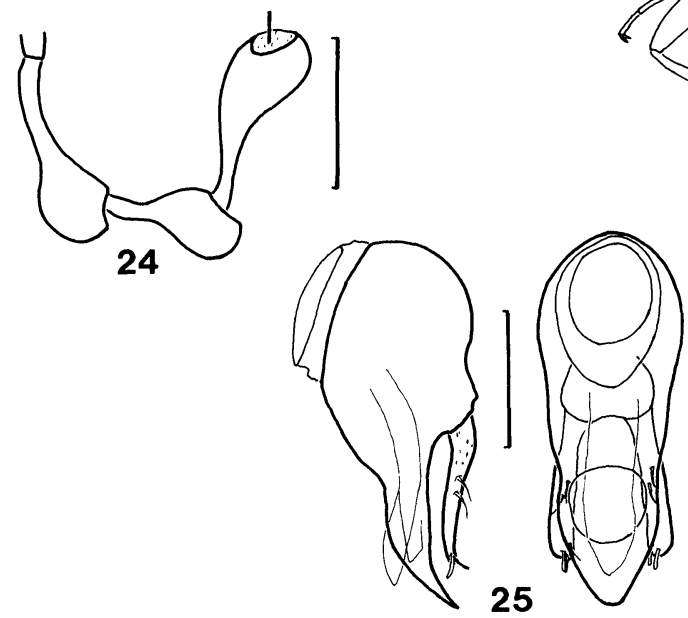

Fig. 22. Tasmanityrus septentrionalis $\mathrm{n}$. $\mathrm{sp}$., right lateral and dorsal view male genitalia, paramere detached.

Fig. 23-25. Chasoke victoriae n. sp. 23. Dorsal habitus; 24. dorsal view right maxillary palpus; 25 . right lateral and dorsal view male genitalia. 


\section{Chasoke n. gen}

This genus cannot be placed near any of the genera of Tyrini from Australia and New Zealand, or indeed near any of the Ethiopian or Neotropical genera discussed and figured by Jeannel $(1959,1962)$. The offset insertion of the last segment of the maxillary palpus (Fig. 24), and large narrow apical flagellomeres (Fig. 23) are suggestive of some members of the Ctenistini. However, it lacks any evidence of lateral spines or setaceous projections on the maxillary palpi, and also lacks squamous pubescence except in the vertexal foveae. Chasoke is readily recognizable in the Australian fauna by the form of the maxillary palpi, pronotum with an antebasal transverse sulcus, and the pubescent vertexal foveae adjacent to the eyes.

Type species, Chasoke victoriae, n. gen., n. sp. Gender, masculine.

Chasoke n. gen. is characterized by: Antennae with long narrow club of 3 flagellomeres, maxillary palpi pedunculate basally, third and fourth segments bowed medially, large pubescent vertexal foveae adjacent to large eyes, small nude fovea at base of antennal tubercle, single gular fovea; pronotum with antebasal transverse sulcus, medial and lateral foveae in sulcus, procoxal foveae present; elytra with two basal foveae, discal stria extending through twothirds of elytral length; median mesosternal fovea forked with forks widely separated at base, lateral mesosternal foveae forked medially and anteriorly, mesocoxal foveae present, single metasternal fovea; tergites I-IV subequal in length, I-III with three baso-lateral foveae, posterior lateral foveae quite small on II-III, IV with two basolateral foveae, V with single lateral fovea, I and II with pair of opposing teeth extending over medial baso-lateral foveae at end of basal impression; sternites II-V with large medio-lateral foveae, III$\mathrm{V}$ with small baso-lateral foveae at margin, II with large globular invagination connected to margin by sulcus, III with small sulcus extending from margin and curved anteriorly; aedeagus with elongate symmetrical parameres.

Chasoke victoriae n. gen., n. sp.

(Figs. 23-25)

Length 1.72-2.25. Males with flagellomeres VII-IX narrow and elongate, VII and VIII about four times as long as wide; abdominal apex narrowly rounded, tergite $\mathrm{V}$ pointed apically, sternites II-VI lightly flattened medially; protrochanters with ventral knob, profemora with two widely spaced ventral knobs in basal half. 
Females with flagellomeres VII-IX wider and shorter, VII no more than three times as long as wide, VIII only twice as long as wide; abdomen broadly rounded at apex, tergite $\mathrm{V}$ slightly tumid medially; knobs of protrochanters and profemora as in males.

Measurements of holotype: Flagellomere VII 0.7 wide, 0.29 long, VIII 0.08 wide, 0.27 long, IX 0.11 wide, 0.31 long; knobs of right profemur 0.08 and 0.24 from base.

Specimens examined, 5: Holotype male, Victoria, Australian Alps, I-1943, C. Oke and M. T. Higgenbotham (MVMA). PARATYPES: 1 male, Australian Alps, V, C. Oke (MVMA); 1 male, Balook, IV-26-1943, C. Oke (DSC); 1 male, 1 female, no locality data (MVMA). Known only from Victoria.

Etymology: The generic name is derived from that of the principal collector of the type series, Charles Oke, and the specific name from the state in which the specimens have been collected.

\section{ACKNOWLEDGMENTS}

I would like to thank the following individuals for the loan of specimens in their care, and the abbreviation for the collections in which specimens are placed follows their affiliation: John F. Lawrence, C.S.I.R.O, Canberra, Australia (ANIC); A. Neboiss, National Museum of Victoria, Abbotsford, Australia (MVMA); S. Endrody-Younga, Transvaal Museum, Pretoria, South Africa (TMSA); A. F. Newton, Field Museum of Natural History, Chicago, arranged the loan of material from that institution (FMNH) and from his private collection (AFN); E. G. Matthews, South Australian Museum, Adelaide, Australia (SAMA), assisted by the loan of the holotype and part of the type-series of Tyromorphus auricomus Lea. Some material is retained in the collection of the author (DSC). J. C. Watt and R. C. Craw, D.S.I.R., Auckland, New Zealand, helped greatly by the loan of specimens of Tyrogetus palpalis Broun and other representatives of the New Zealand Tyrini. J. F. Burger and R. M. Reeves, University of New Hampshire, kindly read the manuscript.

\section{SUMMARY}

The New Zealand tyrine genus Tyrogetus Broun is now recorded from Tasmania with the description of three new species; occidentalis n. sp., howardi n. sp., minimus n. sp. Two new genera of Tyrini 
are described. Tasmanityrus n. gen., is proprosed for Tyromorphus auricomus Lea n. comb., and six new species from Tasmania: hilli $\mathrm{n}$. sp., newtoni n. sp., simplicis n. sp., orientalis n. sp., thayeri n. sp., septentrionalis n. sp. Tasmanityrus is placed nearest Gerallus Sharp. Chasoke victoriae n. gen., n. sp., from Victoria cannot be placed near any particular genus at this time.

\section{Literature Cited}

LeA, A. 1911. (1910). Australian and Tasmanian Pselaphidae. Proc. ent. Soc. N.S.W. 35: 691-772, pl. XXI.

Jeannel, R. 1959. Revision des Pselaphides de l'Afrique intertropicale. Annls Mus. r. Congo belge Ser. 8vo., Sciences Zoologiques 75: 1-742.

Jeannel, R. 1962. Les Pselaphides de la Paleantarctide occidentale, pp. 295-479. In: Deboutteville, C. D. and E. Rapoport, eds., Biologie de l'Amerique australe. Vol. 1, Etudes sur la faune du sol. Centre National de la Recherche Scientifique, Paris. 

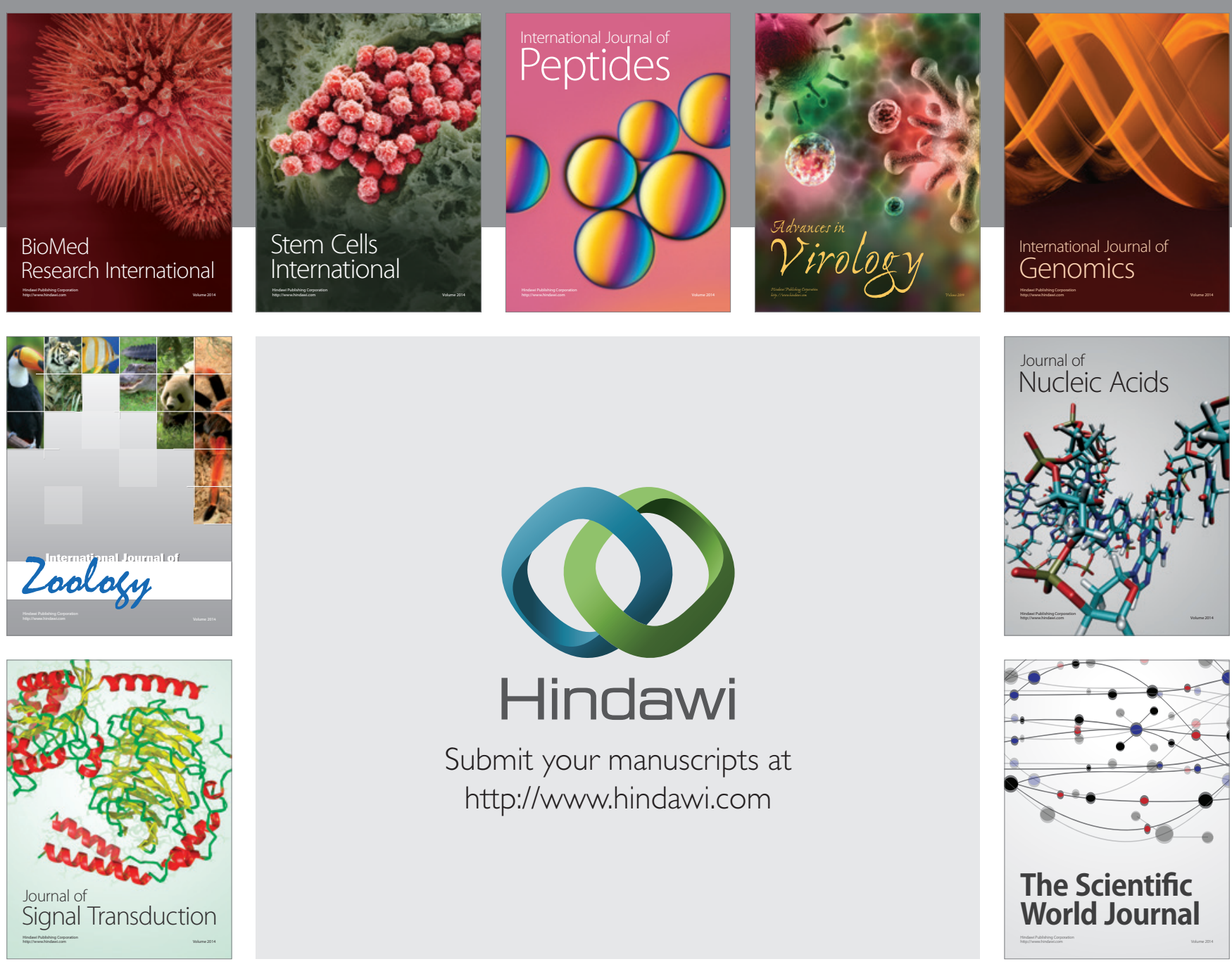

Submit your manuscripts at

http://www.hindawi.com
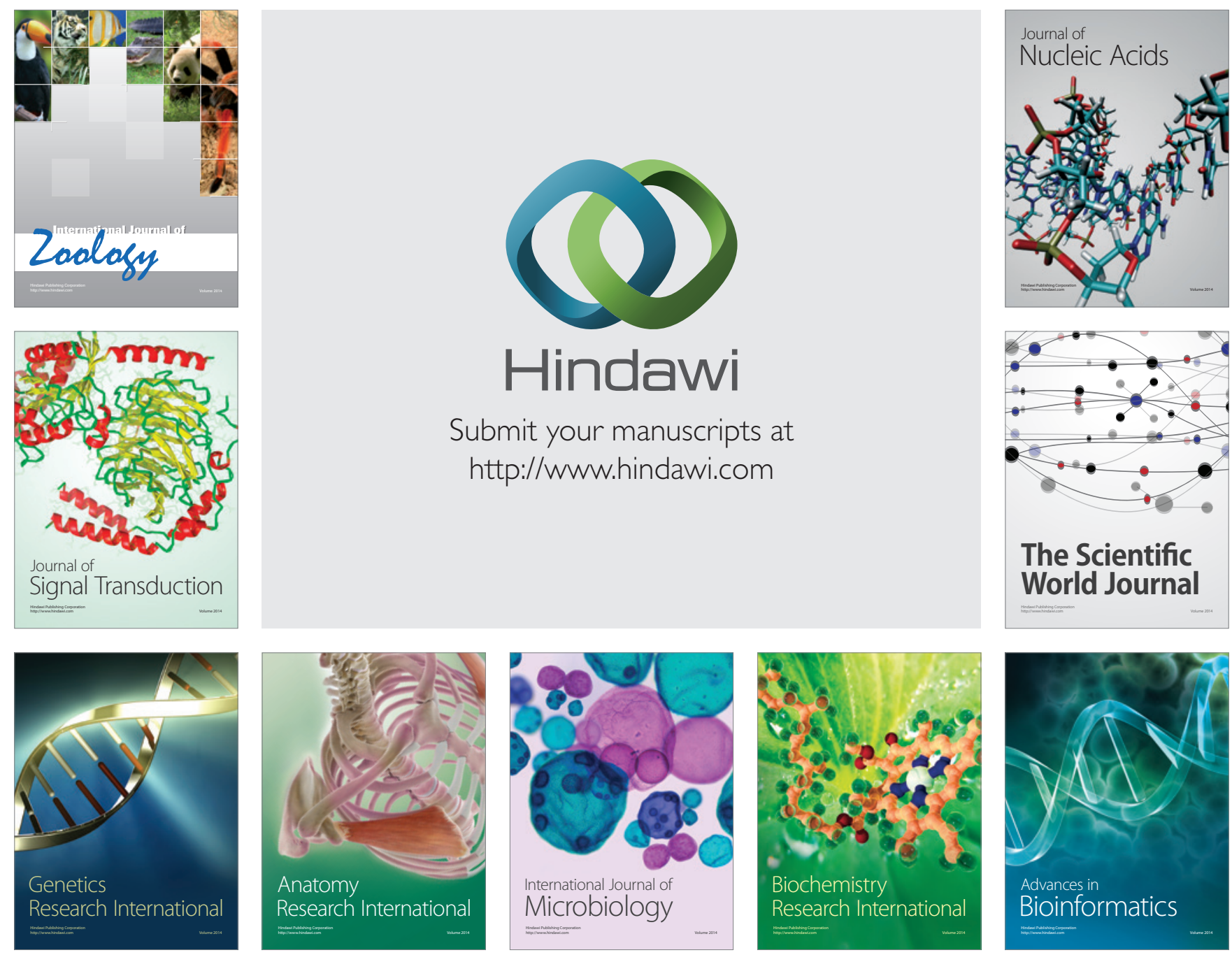

The Scientific World Journal
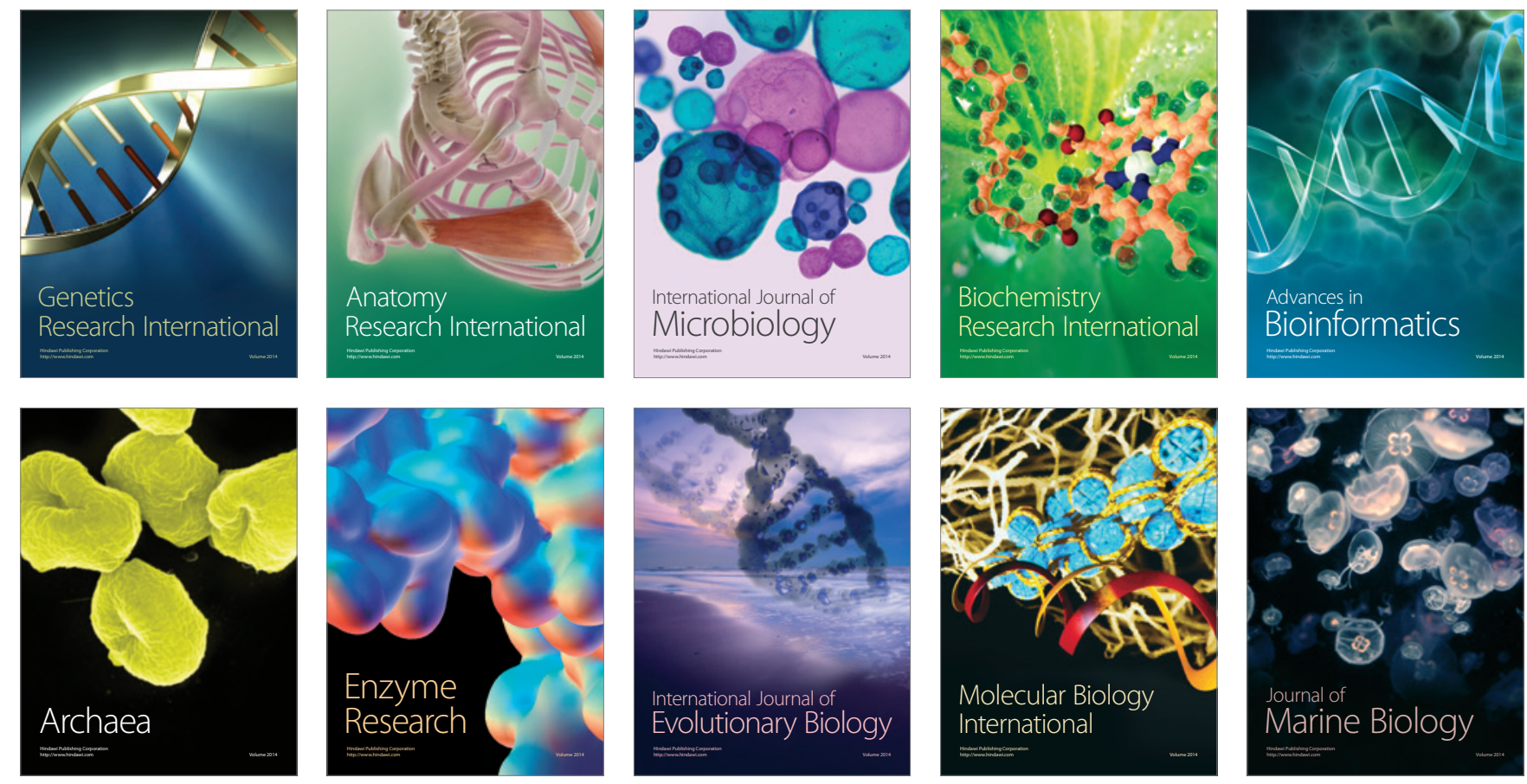